\title{
PENAMPILAN PEDET SAPI BALI HASIL INSEMINASI BUATAN DARI PEJANTAN BERBEDA
}

\author{
DEWANTARI, M. DAN A. A. OKA \\ Fakultas Peternakan Universitas Udayana, Denpasar, Bali. \\ e-mail: dewantari@unud.ac.id
}

\begin{abstract}
ABSTRAK
Inseminasi Buatan (IB) adalah salah satu teknologi reproduksi yang telah berhasil meningkatkan mutu genetik ternak, dan dalam waktu pendek dapat menghasilkan anak dengan kualitas baik dalam jumlah yang besar dengan memanfaatkan pejantan unggul. Penelitian ini bertujuan untuk mengetahui penampilan pedet sapi bali hasil inseminasi buatan dari pejantan yang berbeda. Penelitian menggunakan data primer dan sekunder. Data sekunder berupa catatan berat lahir sapi hasil inseminasi buatan dan data primer merupakan pengukuran berat dan dimensi tubuh anak-anak sapi hasil inseminasi buatan dari pejantan berbeda. Statistik deskriptif digunakan untuk membantu memaparkan keadaan yang sebenarnya dari potensi produksi pejantan yang dipakai sebagai sumber semen sehingga diperoleh data dasar tentang potensi produksi. Hasil penelitian menunjukkan bahwa tidak ada perbedaan bobot lahir pedet sapi dari pejantan berbeda, demikian juga terhadap bobot dan dimensi tubuh pedet sapi pra sapih hasil inseminasi buatan dari pejantan berbeda. Kesimpulan dari penelitian ini bahwa pejantan yang digunakan dalam penelitian ini mempunyai kualitas yang sama.
\end{abstract}

Kata kunci: inseminasi buatan, penampilan produksi, pejantan

\section{THE PERFORMANCE OF BALI CALVES RESULTED FROMARTIFICIAL INSEMINATION USING SEMEN FROM DIFFERENT BALI BULLS}

\begin{abstract}
Artificial insemination (AI) is one of the reproductive technologies that has succeeded in improving the genetic quality of livestock, and in a short time can produce calves in good quality in large numbers by utilizing superior males. This study aims to determine the performance of bali calves from artificial insemination using semen from different bali bulls. The study used primary and secondary data. Secondary data in the form of birth weight records of cows resulting from artificial insemination and primary data is a measurement of the weight and dimensions of the body of calves produced by artificial insemination from different bulls. Descriptive statistics are used to describe the actual condition of the productive potential of the bulls which is used as a source of cement in order to obtain basic data on the productive potential. The results showed that there were no differences in birth weight of calves from different bulls, as well as the body weight and dimensions of pre-weaning calves produced by artificial insemination from different bulls. The conclusion is that the bulls were used in this study have the same quality.
\end{abstract}

Key words: artificial insemination, performance of production, bulls

\section{PENDAHULUAN}

Sapi bali merupakan sapi potong asli Indonesia yang merupakan hasil domestikasi dari banteng (Bos-bibos banteng) dan memiliki potensi besar untuk mensuplai kebutuhan protein hewani (Hardjosubroto, 1994). Di Provinsi Bali populasi sapi potong meningkat dari 553.582 ekor di tahun 2014 menjadi 560. 546 ekor pada tahun 2018 (BPS, 2019). Keberhasilan dalam peningkatan populasi sapi potong di Indonesia berkat keberhasilan program UPSUS SIWAB yang dicanangkan pemerintah sejak empat tahun terakhir. Dalam program tersebut salah satunya adalah pelayanan inseminasi buatan (IB) secara gratis kepada peternak. Pelaksanaan IB telah berkembang dan tersebar di seluruh Indonesia. Keberhasilan IB itu sendiri sangat dipengaruhi oleh kualitas semen beku yang dipergunakan yang berasal dari pejantan terpilih, disamping oleh beberapa faktor seperti ketrampilan inseminator IB baik dalam penanganan semen beku maupun dalam memposisikan semen di dalam saluran reproduksi betina, serta kemampuan peternak akseptor IB dalam mengenali 
tanda-tanda birahi dari sapi miliknya.

Pejantan merupakan hal yang harus diperhatikan dalam usaha meningkatkan populasi dan produktivitas dalam peternakan sapi potong/pedaging. Pejantan akan mengawini induk sehingga terjadi kebuntingan dan menghasilkan pedet yang baru. Bobot lahir juga tidak terlepas dari pengaruh pejantan dimana hanya pejantan tertentu yang dapat menghasilkan bobot lahir yang tinggi. Penelitian Galuh et al. (2014) tentang pengaruh pejantan sebagai sumber semen terhadap penampilan reproduksi memperoleh hasil rataan bobot lahir adalah $16,55 \pm 1,81 \mathrm{~kg}$. Rataan bobot lahir pedet jantan dan pedet betina masing-masing adalah $16,62 \pm 2,08 \mathrm{~kg}$ dan $16,44 \pm 1,29 \mathrm{~kg}$. Pengaruh perbedaan pejantan tidak menunjukkan perbedaan yang nyata $(\mathrm{P}>0.05)$ terhadap lama bunting dan bobot lahir.

Bobot lahir merupakan faktor yang penting dalam pertumbuhan pedet sapi. Sapi dengan bobot lahir yang besar dan lahir secara normal akan lebih mampu mempertahankan kehidupannya. Seperti yang telah dinyatakan oleh Muzani et al. (2004) bahwa beberapa faktor yang mempengaruhi bobot lahir antara lain pejantan, bangsa, genetik, jenis kelamin pedet, lama kebuntingan, umur induk dan berat induk. Perbedaan bobot lahir pedet sapi bali antara kawin alam dan IB di Kecamatan Jonggat Lombok Tengah diteliti oleh Wiramaya (2014). Rataan bobot lahir pedet hasil IB adalah 14,845 $\mathrm{kg}$ dibandingkan dengan bobot lahir pedet sapi hasil kawin alam yang hanya $10,55 \mathrm{~kg}$. Bobot lahir anak sapi bali hasil penelitian Prasojo et al. (2010)

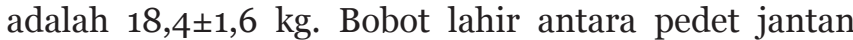
dan pedet betina sangat bervariasi. Kisaran bobot lahir pedet jantan antara 10,5 sampai dengan 22,0 kg dengan rata-rata $18,9 \pm 1,4 \mathrm{~kg}$. Sementara pedet betina memiliki kisaran bobot lahir antara 13 sampai dengan $26 \mathrm{~kg}$ dengan rataan 17,9 $\pm 1,6 \mathrm{~kg}$. Kadarsih (2004) melaporkan bahwa bobot badan pedet sapi bali di Bengkulu antara jantan dan betina berbeda. Pedet sapi bali jantan bobot badannya 15,55-17,11 kg sedangkan pedet sapi bali betina hanya 14,41-16,09 kg. Hasil ini diperkuat oleh laporan Setiyabudi et al. (2016) yang menyatakan bahwa bobot lahir pedet jantan lebih berat $(18,04 \pm 1,38 \mathrm{~kg})$ dari pada pedet betina $(17,79 \pm 1,14 \mathrm{~kg})$. Selanjutnya dilaporkan bobot badan pedet sapi juga dipengaruhi oleh ketinggian tempat. Peneliti tersebut juga melaporkan bahwa di dataran tinggi pedet sapi jantan ataupun pedet sapi betina menunjukkan bobot badan yang lebih berat dibandingkan dengan anakanak sapi yang induknya dipelihara di dataran berbukit ataupun dataran rendah. Berdasarkan uraian diatas maka penampilan pedet hasil IB dari pejantan yang berbeda akan dibahas dalam artikel ini.

\section{MATERI DAN METODE}

Materi yang digunakan dalam penelitian ini terdiri dari: (1) Catatan bobot anak- anak sapi hasil IB yang diperoleh dari data peternakan di UPT Pembibitan Sapi Sobangan; (2) Catatan anak sapi pra sapih dari peternakan sapi akseptor IB di UPT Pembibitan Sapi Sobangan. Pengumpulan data dilakukan menggunakan 2 (dua) metode yaitu data sekunder berupa catatan bobot badan anak- anak sapi dari beberapa pejantan yang berbeda, dan data primer dari pengukuran langsung terhadap beberapa parameter yang mencakup: (1) bobot badan anak sapi pra sapih, yaitu dengan menimbang anak-anak sapi tersebut menggunakan timbangan digital; (2) melakulan pengukuran panjang badan anakanak sapi hasil IB; (3) melakukan pengukuran tinggi gumba dari anak-anak sapi pra sapih; dan (4) melakukan pengukuran lingkar dada anak-anak sapi pra sapih. Dimensi tubuh diukur dengan mengunakan tongkat ukur dan pita ukur, dimana pengukuran dilakukan di kandang jepit (kandang fiksasi). Adapun pengukuran sebagai berikut: (1) Panjang badan yaitu jarak lurus antara tonjolan bahu (tuberosity of humerus) sampai tulang duduk atau tulang tapis (tuber ischii) pada sisi yang sama; (2) Lingkar dada yaitu lingkaran yang diukur pada dada, persis dibelakang siku tegak lurus dengan sumbu tubuh; dan (3) Tinggi gumba yaitu jarak tegak lurus dari titik tertinggi pundak (gumba) sampai ke tanah atau lantai.

Data primer dan sekunder yang didapat ditabulasi selanjutnya dianalisis secara deskriptif. Untuk melihat perbedaan bobot lahir diantara dua pejantan yang digunakan, serta perbedaan bobot badan, panjang badan, lingkar dada dan tinggi gumba antara jantan dan betina, digunakan uji $\mathrm{T}$ (two independent sample T-test) menurut Steel and Torrie,1995 dan SPSS versi 16.

\section{HASIL DAN PEMBAHASAN}

Hasil penelitian tentang penampilan pedet sapi bali hasil IB dari pejantan berbeda (Tabel 1) menunjukkan bahwa persentase kelahiran pedet yaitu: $47 \%$ jantan berbanding $53 \%$ betina di tahun $2017,59 \%$ jantan berbanding 46\% betina di tahun 2018 dan 66,7\% berbanding $33,3 \%$ betina di tahun 2019. Secara teori, perbandingan jantan dan betina adalah $50 \%$ jantan dan 50\% betina, hal ini disebabkan karena ada beberapa perlakuan pada semen yang menyebabkan terjadi perubahan pada imbangan persentase kelahiran jantan dan betina. 
Tabel 1. Persentase kelahiran pedet sapi bali jantan dan betina hasil inseminasi buatan di Sobangan tahun 2017-2019

\begin{tabular}{lccc}
\hline \multicolumn{1}{c}{ Tahun } & Jantan & Betina & Total \\
\hline 2017 & $54(46,95 \%)$ & $61(53,05 \%)$ & 115 \\
2018 & $65(58,56 \%)$ & $46(41,44 \%)$ & 111 \\
2019 (Januari-Agustus) & $38(66,67 \%)$ & $19(33,33 \%$ & 57 \\
\hline
\end{tabular}

Penampilan pedet sapi bali hasil penelitian menunjukkan bahwa rataan bobot lahir sapi bali dari pejantan I adalah 16,40 kg untuk anak betina sedangkan anakjantan rataan bobot lahirnya $17,5 \mathrm{~kg}$, secara statistik tidak ada perbedaan yang signifikan antara bobot lahir anak jantan dan anak betina $(\mathrm{P}>0,05)$ sedangkan rataan bobot lahir anak sapi bali betina sebesar 16,50 kg dan jantan $17,4 \mathrm{~kg}$ dari pejantan II juga tidak berbeda nyata secara statistik $(\mathrm{P}>0,05)$ seperti disajikan pada Tabel 2.

Tabel 2. Penampilan pedet sapi bali jantan dan betina hasil inseminasi buatan (IB) dari pejantan yang berbeda

\begin{tabular}{cccc}
\hline Variabel & Pejantan 1 & Pejantan 2 & SEM ${ }^{1)}$ \\
\hline Bobot lahir (betina) & $6,40{ }^{a}$ ) & $16,50{ }^{a}$ & 0,054 \\
Bobot lahir (jantan) & $17,50{ }^{a}$ & 17,40 & 0,039 \\
\hline
\end{tabular}

Keterangan:

1) SEM: Standard Error of Means

2) Nilai dengan huruf yang sama pada baris yang sama menunjukkan perbedaan yang tidak nyata $(P>0,05)$

Hasil ini menunjukkan bahwa tidak ada perbedaan bobot lahir antara anak jantan dan betina serta tidak ada perbedaan antara bobot lahir dari 2 (dua) pejantan berbeda. Hasil ini sesuai dengan hasil peneltian Galuh et al. (2014) tentang pengaruh pejantan sebagai sumber semen terhadap penampilan reproduksi memperoleh hasil rataan bobot lahir adalah $1,55 \pm 1,81 \mathrm{~kg}$. Rataan bobot lahir pedet jantan dan pedet betina masingmasing adalah 16,62 $\pm 2,08 \mathrm{~kg}$ dan $16,44 \pm 1,29 \mathrm{~kg}$. Hasil penelitian tentang bobot lahir sapi bali ini lebih tinggi dari hasil penelitian Wiramaya (2014) yang mendapat bobot lahir sapi bali hasil IB di Lombok Timur lebih ringan yaitu $14,845 \mathrm{~kg}$ tetapi lebih ringan dari hasil penelitian Prasojo (2010) yang mendapat rataan bobot lahir pedet jantan $18,9 \pm 1,4 \mathrm{~kg}$ dan rataan bobot lahir pedet betina $17,9 \pm 1,6 \mathrm{~kg}$.

Rataan bobot badan dan dimensi tubuh pedet sapi bali jantan dan betina pra-sapih hasil I disajikan pada Tabel 3. Hasil penelitian menunjukkan bahwa rataan bobot badan sapi pra-sapih antara jantan dan betina berbeda tidak nyata $(\mathrm{t}$-hitung $=0,0684<\mathrm{t}$-tabel $=$ 2,0167). Demikian juga pada dimensi tubuh lainnya, yaitu terhadap rataan panjang badan ( $\mathrm{t}$-hitung = o,0587), rataan lingkar dada (t- hitung $=0,0311$ ) dan rataan tinggi gumba (t-hitung $=0,1342$ ) antara anak sapi jantan dan betina pra-sapih hasil inseminasi buatan berbeda tidak nyata. Ini berarti tidak ada perbedaan rataan bobot badan, panjang badan, lingkar dada dan tinggi gumba antara jantan dan betina anak sapi pra sapih hasil inseminasi buatan.
Tabel 3. Rataan bobot badan dan dimensi tubuh luar pedet sapi bali jantan dan betina pra-sapih hasil inseminasi buatan

\begin{tabular}{lcc}
\hline \multicolumn{1}{c}{ Variabel } & Jantan & Betina \\
\hline Bobot badan $(\mathrm{kg})$ & $36,92^{\mathrm{a} 1 \mathrm{a}} \mathrm{a} \pm 14,09$ & $40,56 \mathrm{a}^{\mathrm{a}} \pm 20,10$ \\
Panjang badan $(\mathrm{cm})$ & $60,10^{\mathrm{a}} \pm 12,21$ & $57,88^{\mathrm{a}} \pm 11,38$ \\
Lingkar dada $(\mathrm{cm})$ & $79,17 \mathrm{a}^{ \pm} \pm 11,79$ & $80,43 \mathrm{a}^{ \pm 14,70}$ \\
Tinggi gumba $(\mathrm{cm})$ & $72,500^{\mathrm{a}} \pm 7,77$ & $76,09{ }^{\mathrm{a}} \pm 9,71$ \\
\hline
\end{tabular}

Keterangan:

1) SEM: Standard Error of Means

${ }^{2)}$ Nilai dengan huruf yang sama pada baris yang sama menunjukkan perbedaan yang tidak nyata $(P>0,05)$

\section{SIMPULAN}

Berdasarkan hasil penelitian maka dapat disimpulkan bahwa penampilan produksi (bobot lahir dan bobot pra sapih serta dimensi tubuh pedet ) sapi bali hasil inseminasi buatan dari pejantan yang berbeda adalah sama

\section{UCAPAN TERIMAKASIH}

Terima kasih kepada Rektor, Ketua Lembaga Penelitian dan Pengabdian Masyarakat serta Dekan Fakultas Peternakan atas dana Hibah Unggulan Program Studi yang diberikan, juga kepada UPT Pembibitan Sapi Bali di Sobangan atas kerjasamanya dalam pelaksanaan penelitian.

\section{DAFTAR PUSTAKA}

Badan Pusat Statistik [BPS]. 2019. Perkembangan Penduduk Indonesia. Sumber: https://www.bps.go.id/. Diakses 05 September 2019.

Galuh R. K. P., I N. Ardika dan N. M. Artiningsih R. 2014. Pengaruh Perbedaan Pejantan Sebagai Sumber Semen terhadap Performans Reproduksi Sapi Bali Di Sentra Pembibitan Sapi Bali Sobangan. E-Jurnal Peternakan Tropika. Fakultas Peternakan. Universitas Udayana.

Hardjosubroto, W. 1994. Aplikasi Pemuliabiakan Ternak di Lapangan. PT. Gramedia Widiasarana Indonesia. Jakarta.

Kadarsih, S. 2004. Performans Sapi Bali Berdasarkan Ketinggian Tempat di Daerah Transmigrasi Bengkulu: I Performans Pertumbuhan. Jurnal Ilmu-Ilmu Pertanian 6 (1): 50-56.

Muzani, A., W. R. Sasongko, dan T. S. Panjaitan. 2004. Dampak Penerapan Paket Manajemen Terpadu terhadap Bobot Lahir dan Pertambahan Bobot Badan Harian Prasapih Ternak Sapi Bali. Balai Pengkajian Teknologi Pertanian Nusa Tenggara Barat.

Prasojo, G., I. Arifiantini, dan K. Mohamad. 2010. Korelasi antara Lama Kebuntingan, Bohot Lahir fan Jenis Kelamin Pedet Hasil Inseminasi Buatan Pada Sapi Bali. Institut Pertanian Bogor.Bogor. 
Setiyabudi, R. J. W., Muladno, dan R. Priyanto. 2016. Pendugaan Parameter Genetik Sifat Pertumbuhan Sapi Bali di BPTU HPT Denpasar. Jurnal Ilmu Produksi dan Tehnologi Hasil Peternakan Vol. 04 No.3 Oktober 2016. Hal. 327-333

Steel R. G. D. and J. H. Torrie. 1995. Prinsip dan Prosedur Statistika. Penerjemah: Sumantri B. Ed ke-4. Jakarta: Gramedia.

Wiramaya, L. 2014. Perbedaan Berat Lahir Pedet Sapi Bali Antara Kawin Alam dan Inseminasi Buatan Di Kecamatan Jonggat Lombok Tengah. Skripsi FKH Unram. Nusa Tenggara Barat. 